\title{
Diluents Role in Extraction and Possible Separation of Light Rare Earth Elements from Chloride Solutions by using Cyanex ${ }^{\circledR} 272$ used as an Extractant
}

\author{
Rajesh Kumar Jyothi' ${ }^{1}$, Hae-Rim Kim ${ }^{3}$, Joon Soo Kim ${ }^{2}$, Kyeong-Woo Chung ${ }^{1}$, and Jin-Young Lee ${ }^{1, *}$ \\ ${ }^{1}$ Korea Institute of Geoscience and Mineral Resources (KIGAM), Daejeon 34132, Republic of Korea \\ ${ }^{2}$ Dept. of Energy Resources Engineering, Chonnam National University, Gwangju 61186, Republic of Korea \\ ${ }^{3}$ Mineral Processing Team, Korea Resources Corporation (KORES), Wonju 26464, Republic of Korea
}

\begin{abstract}
The present paper deals with liquid-liquid extraction studies and the possible separation of light rare earths (LREs) from chloride solutions. Aromatic diluents such as benzene, toluene and xylene were tested for LREs extraction and possible separation from chloride solutions. Bis(2,4,4-triethylpentyl)phosphinic acid (trade name Cyanex ${ }^{\circledR}$ 272) was used as an extractant and dissolved in the diluents. Various experimental parameters such as time effect, influence of $\mathrm{pH}$, extractant concentration variation and maximum loading capacity of the target LREs to Cyanex ${ }^{\circledR} 272$ were examined. Finally, the separation potential of each of the other LREs was calculated, and a suitable diluent system was proposed. The highest separation factors were found using the present systems.
\end{abstract}

(Received July 18, 2018; Accepted September 3, 2018)

Keywords: light rare earth elements, chloride solutions, extraction, separation, Cyanex ${ }^{\circledR} 272$

\section{INTRODUCTION}

Rare earth (RE) elements have similar chemical properties, making them difficult to separate from each other. REs are utilized in clean energy, advanced electronics [1,2] and environmental technology applications [3]. REs such as dysprosium, neodymium, terbium and yttrium are the most important elements for clean energy technologies (including wind turbines, electric vehicles, fluorescent lighting, and photovoltaic cells). The global reserves of REs are in China (38\%, $36 \mathrm{Mt})$, the Former Soviet Union (19\%, $19 \mathrm{Mt})$, the USA (22\%, $22 \mathrm{Mt})$, Australia (5\%, $5.4 \mathrm{Mt})$, India (3\%, 3 $\mathrm{Mt})$, and other countries worldwide (22\%, $22 \mathrm{Mt})$. China produced $97 \%$ of the world's rare earth oxides (REOs) in 2009 , followed by India (2.1\%), Brazil (0.5\%), and Malaysia $(0.3 \%)$ [4]

The literature reports that few attempts have been made to develop light rare earth (LRE) processing and separation. Mainly phosphorus-based extractants, 2-ethylhexyl phosphonic acid mono-2-ethyl hexyl ester (HEHEHP, Daihachi Chem-

*Corresponding Author: Jin-Young Lee [Tel: +82-42-868-3468, E-mail: jinlee@kigam.re.kr] Copyright (c) The Korean Institute of Metals and Materials ical), di-2-ethylhexyl phosphoric acid (D2EHPA) and bis(2,4,4-trimethylpentyl)phosphinic acid Cyanex ${ }^{\circledR} 272$ (from Solvay) have been utilized for LRE processing. Recently studies have been reported of LRE separation using continuous liquid-liquid extraction (CLLE) with HEHEHP) extractants, and lactic acid added to the feed aqueous. Adding lactic acid increased $\mathrm{Pr}$ and $\mathrm{Nd}$ extraction efficiencies from $22 \%$ to $92 \%$ and $30 \%$ to $96 \%$ respectively [5]. Another study determined the separation possibilities of heavy metals and LRE's from phosphoric acid solutions using an acidic organophosphorus reagent, Talcher organo phosphorus solvent (TOPS 99) which is more effective at low acidities [6].

A work has been done on saponification of Cyanex ${ }^{\circledR} 272$ to minimize lanthanum co-extraction and it was found that $50 \%$ saponification (replacing the $\mathrm{H}+$ on the organic with $\mathrm{Na}+$ ) could suppress La extraction. A McCabe-Thiele diagram was generated with $2 \mathrm{~mol} / \mathrm{L}$ Cyanex $^{\circledR} 272$ in Escaid $^{\mathbb{R}} 110$ (Exxon) diluent. It predicted that at an $\mathrm{A} / \mathrm{O}$ ratio of 2 , three extraction stages are required for the maximum $\mathrm{Pr}$ and $\mathrm{Nd}$ extraction. A counter-current extraction (CCE) study using $2 \mathrm{~mol} / \mathrm{L}$ Cyanex ${ }^{\circledR} 272$ (50\% saponified) gave results of $77 \mathrm{mg} / \mathrm{L} \mathrm{La}, 230 \mathrm{mg} / \mathrm{L} \mathrm{Pr}$ and $657 \mathrm{mg} / \mathrm{L} \mathrm{Nd}$ in the loaded organic. The co-extracted lanthanum was scrubbed off the 
loaded organic using a $\mathrm{Nd}$ solution $(780 \mathrm{mg} / \mathrm{L} \mathrm{Nd}, \mathrm{pH} 0.5)$ The scrubbed organic, now holding only $\mathrm{Pr}$ and $\mathrm{Nd}$, was stripped with $1 \mathrm{~mol} / \mathrm{L} \mathrm{HCl} \mathrm{[8].}$

In another study, a $10 \%$ saponified Cyanex ${ }^{\circledR} 272$ (1 $\mathrm{mol} / \mathrm{L})$ in Escaid $^{\circledR} 110$ single system as well as a mixed system, were tested with the addition of either Versatic-10 or tri-n-butyl phosphate (TBP). Best results were obtained using $1 \mathrm{~mol} / \mathrm{L} \quad$ Cyanex $^{\circledR} \quad 272 \quad(10 \%$ saponified) mixed with $0.5 \mathrm{~mol} / \mathrm{L}$ TBP. With this mixture, the produced loaded organic contained $300.5 \mathrm{mg} / \mathrm{L} \mathrm{Nd}$, $95.3 \mathrm{mg} / \mathrm{L}$ Pr but only $16.2 \mathrm{mg} / \mathrm{L} \mathrm{La}$. The organic was well stripped by $1 \mathrm{~mol} / \mathrm{L} \mathrm{HCl}$ [9].

The diluent effect on rare earths extraction was studied a long time ago (1976), using methyl-n-diheptyl amine dissolved in various diluents such as mesitylene, p-xylene, toluene, benzene and nitro-benzene [10]. The highest separation coefficient 84 calculated in benzene diluent in between cerium and lutetium; whereas, cerium between praseodymium, separation coefficient was 2.3 and cerium and neodymium, separation coefficient was 4.6 reported in benzene diluent. This old report disclosed that solvation energy plays a key role in rare earths extraction and separation [10]. Another more recent attempt (2012) of rare earths extraction, from the behavior of chloride solutions in various diluents, was reported using $\mathrm{N}, \mathrm{N}, \mathrm{N}^{\prime}, \mathrm{N}^{\prime}$-tetrabutyl-3oxy-glutaramide (TBDGA) as an extractant system [11]. The extraction efficiency of rare earths followed the order: toluene $<$ n-octane $<\mathrm{CCl}_{4}<\mathrm{CHCl}_{3}$. All the extraction reactions were exothermic by nature. Solvent extraction of RARE EARTHS (Pr \& Na) from chloride solutions was developed by L1 $\times 63$ of an extractant system [12].

The literature survey led to the further investigation of a viable extractant system for LRE processing. The present study focuses on the effect of the nature of the diluent on extraction, as well as on the separation of lanthanum, cerium, praseodymium and neodymium from each other.

\section{EXPERIMENTAL}

\subsection{Apparatus and reagents}

A master synthetic leach liquor was used here, prepared by dissolving LRE oxides in hydrochloric acid solutions. In every experiment, after $\mathrm{pH}$ adjustment with $\mathrm{NaOH}$ solution, the adjusted feed solution was separately analyzed. The LRE concentrations on the loaded organic were calculated by mass balance using feed and raffinate assays. The average of all the feed assays was: La- $125 \pm 5$; Ce- $21 \pm 2$; Pr- $27 \pm 2$, and $\mathrm{Nd}-72 \pm 2 \mathrm{mg} / \mathrm{L}$.

For the LRE analysis, an inductively coupled plasma optimal emission spectrometer (ICP-OES, Thermo Scientific, USA, model iCAP 6000 Series) was used. An Orion Star A215 pH/conductivity meter was used for the pH measurements. A shaking incubator (model: SI-300/ 300R/600/600R) was used for the liquid-liquid extractions. The commercial-grade Cyanex ${ }^{\circledR} 272$ was supplied by Cytec, Canada and used as received. It was diluted to the desired concentration in the three aromatic diluents (GR Grade), benzene, toluene and xylene that were investigated. The diluents were obtained from Aldrich Chemicals. All other reagents used were of analytical reagent grade.

\subsection{Liquid-Liquid-Extraction procedure}

Equal volumes of the organic mixture being tested and a chloride aqueous phase containing four LRE's ( $\mathrm{La}, \mathrm{Ce}, \mathrm{Pr}$, and $\mathrm{Nd}$ ) were shaken in a separatory funnel mounted in a shaking incubator. The set-point temperature was $25 \pm 1{ }^{\circ} \mathrm{C}$ and the shaking speed was $250 \mathrm{rpm}$. Except for the extraction kinetics experiment, the extraction time was set to $10 \mathrm{~min}$. Separation time after shaking was $30 \mathrm{sec}$. The feed and raffinate solutions were analysed for LRE content by ICPOES. The loaded organic LRE concentration was calculated by mass balance.

\subsection{Formulas}

$$
\begin{aligned}
& \text { Metal }_{\text {organic }}=\text { Metal }_{\text {feed }}-\text { Metal }_{\text {raffinate }} \\
& \text { Distribution ratio, D }=\text { Metal }_{\text {organic }} / \text { Metal }_{a q} \\
& \text { Extraction, } \%=100 \times D /(D-A / O \text { ratio })
\end{aligned}
$$

where $\mathrm{D}=$ Distribution ratio (concentration of the metal in organic phase / concentration in aqueous phase)

$$
\text { Separation factor, } \beta=D_{M 1} / D_{M 2}
$$

where, DM1 $=$ Distribution ratio of metal 1 and DM2 = Distribution ratio of metal 2 


\section{RESULTS AND DISCUSSION}

\subsection{Kinetic studies}

Kinetic studies are needed to determine the test conditions for equilibrium studies. Metal extraction processes are governed by the mass transfer and diffusion rates. The very fast kinetics of extraction allows the use of contactors which have retention times on the order of seconds. A series of kinetics tests were conducted under standard conditions $(\mathrm{A} / \mathrm{O}$ $=1,25^{\circ} \mathrm{C}$ ) and the initial $\mathrm{pH}$ condition of the aqueous feed solutions, 5.6 \pm 0.1 . Samples were taken at different contact times. The obtained experimental data are presented in Figure 1. From the figure, it is clear that the extraction of all four LRE's reached equilibrium quickly in all three diluent systems. Therefore, in all of the subsequent experiments, extraction time was set to $10 \mathrm{~min}$.

\subsection{The Influence of $\mathrm{pH}$}

The effect of $\mathrm{pH}$ in the range from 1 to $5.6 \pm 0.1$ was studied in tests using $0.7 \mathrm{~mol} / \mathrm{L}$ Cyanex ${ }^{\circledR} 272$ dissolved in the three diluents, benzene, toluene or xylene. All contacts were at a phase ratio $(\mathrm{O} / \mathrm{A})$ of 1 at $25^{\circ} \mathrm{C}$. The LRE synthetic solution feed analysis was (in $\mathrm{mg} / \mathrm{L}$ ): $\mathrm{Ce}=26, \mathrm{La}=126, \mathrm{Pr}$ $=27$, and $\mathrm{Nd}=66$.

The obtained results are presented in Figure 2. The four LRE's are adjacent in the lanthanide series in terms of atomic numbers from 57 for La to 58 for Ce, 59 for Pr and 60 for $\mathrm{Nd}$. The extraction efficiency of the four LRE's followed the order from heaviest $(\mathrm{Nd})$ to lightest $(\mathrm{La})$. Extraction was unsatisfactory at pH's below 2.0 and it was concluded that mid-range $\mathrm{pH}$ values from 3 to 5.6 (equilibrium $\mathrm{pH} 2.6 \pm 0.2$ ) gave the best extractions of the LRE's in all three diluent systems.

\subsection{Effect of the extractant concentration}

The extractant concentration was varied in the range between 0.01 and $1.0 \mathrm{~mol} / \mathrm{L}\left(\mathrm{Cyanex}^{\circledR} 272\right)$ while other parameters were kept the same, as in the work at $0.7 \mathrm{~mol} / \mathrm{L}$ extractant. The feed $\mathrm{pH}$ range studied was 3 to 5.6. The percent extracted increased with increasing extractant concentration. In the case of lanthanum, even $1.0 \mathrm{~mol} / \mathrm{L}$ of the extractant was not able to extract more than $30 \%$ (Figure 2 to 4$)$.
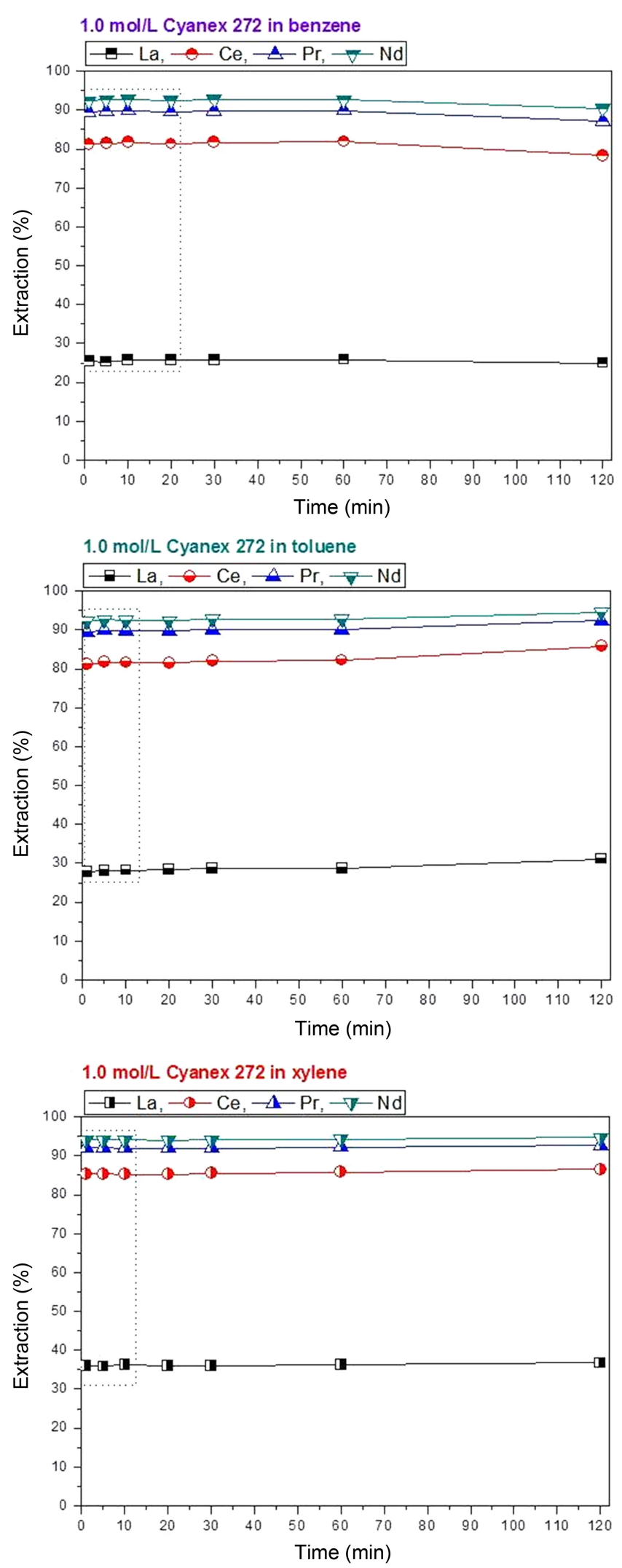

Fig. 1. Kinetics of LRE extraction using $1 \mathrm{~mol} / \mathrm{L}$ Cyanex ${ }^{\circledR} 272$ in the three diluents tested 

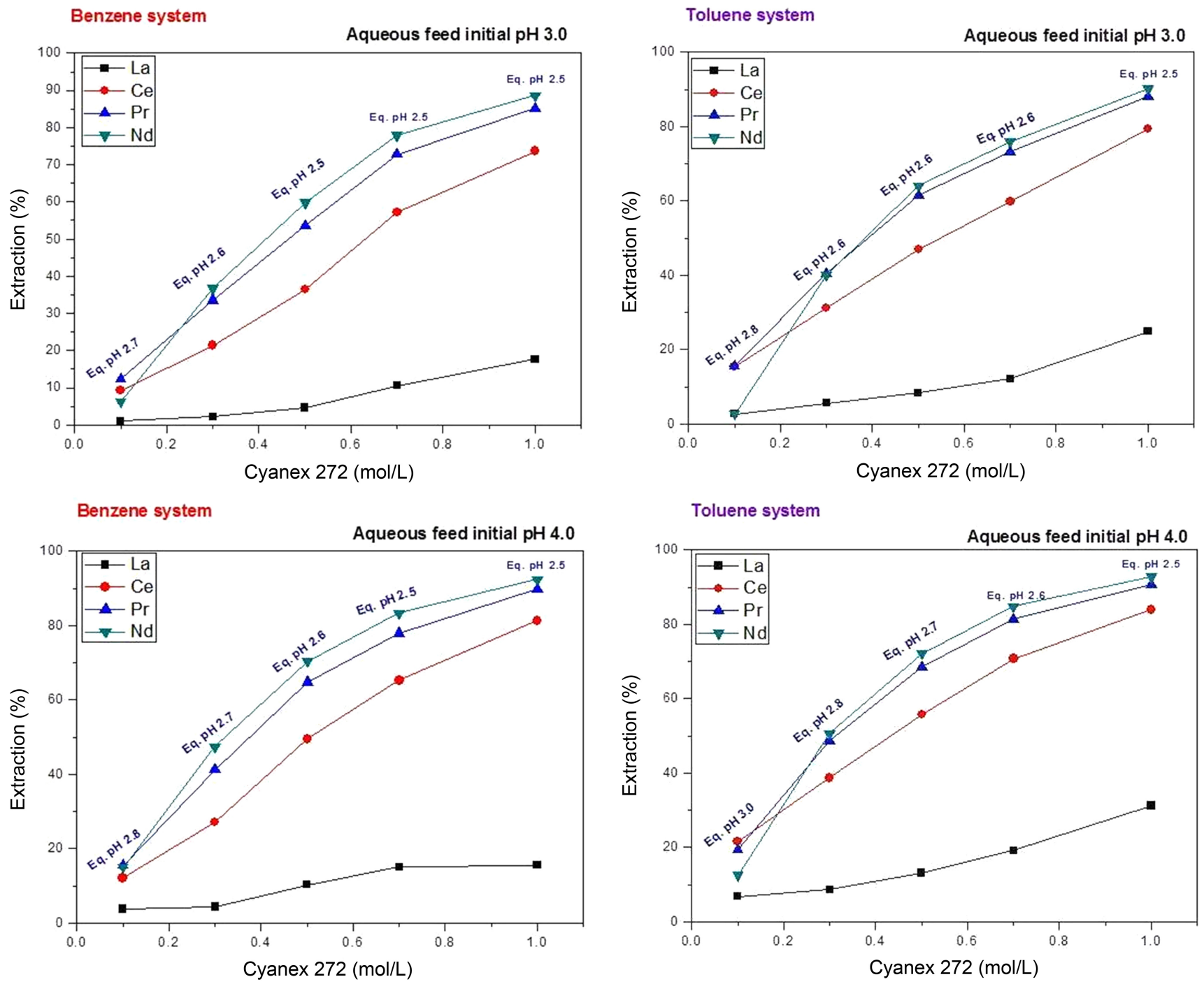

Benzene system

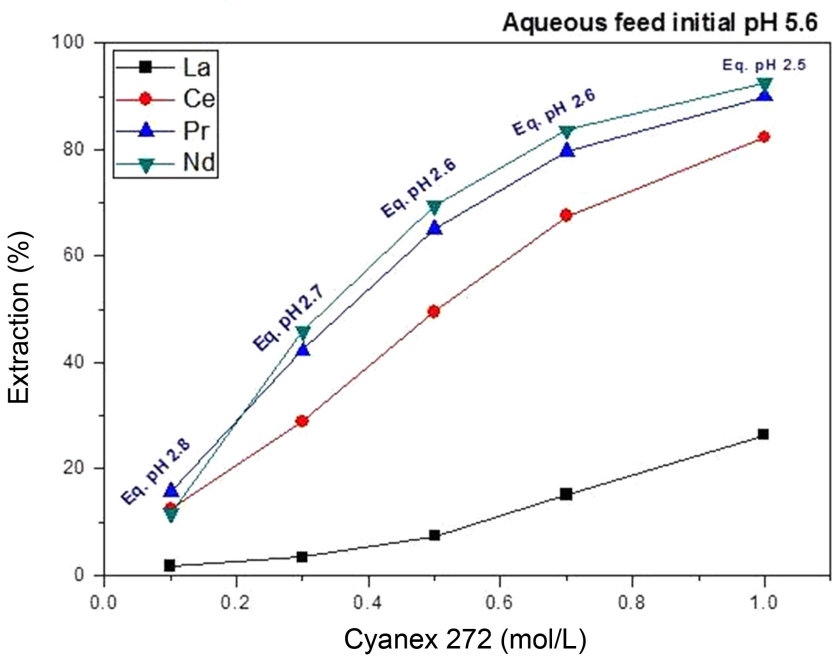

Toluene system

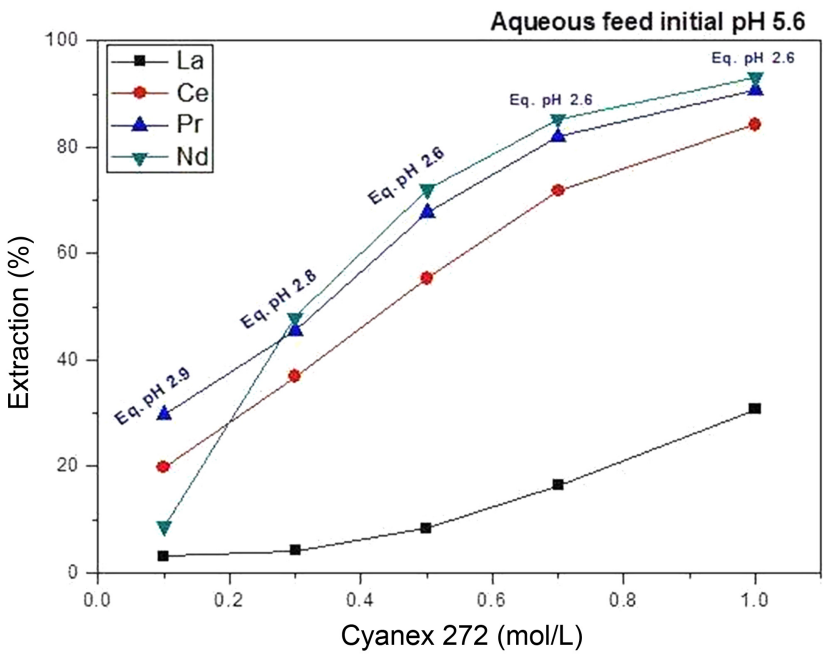

Fig. 2. Influence of the $\mathrm{pH}$ on the extraction and possible separation of LRE's using Cyanex ${ }^{\circledR} 272$ as an extractant diluted in benzene.

Fig. 3. Influence of the $\mathrm{pH}$ on the extraction and possible separation of LRE's using Cyanex ${ }^{\mathbb{R}} 272$ as an extractant diluted in toluene. 


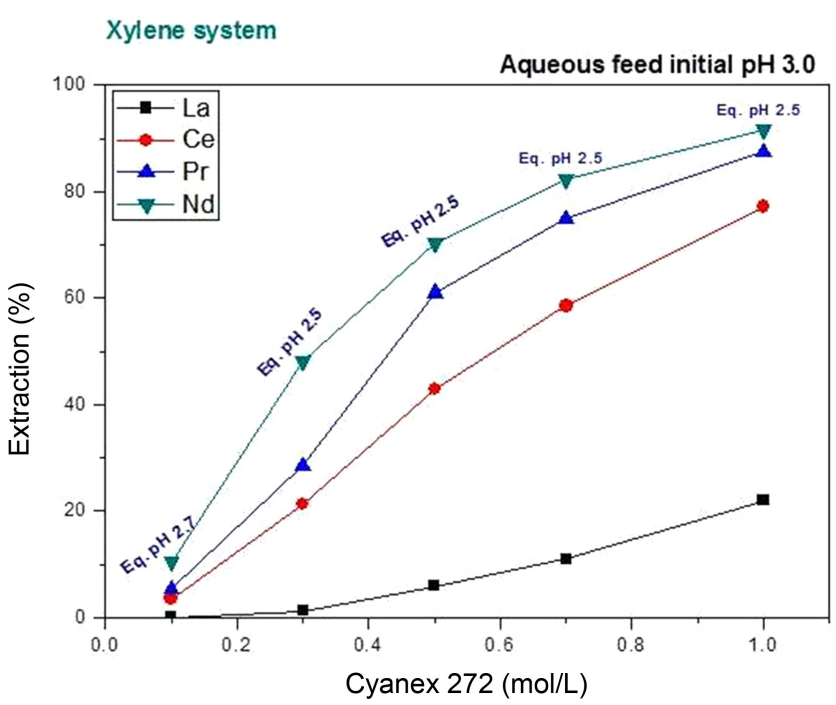

Xylene system
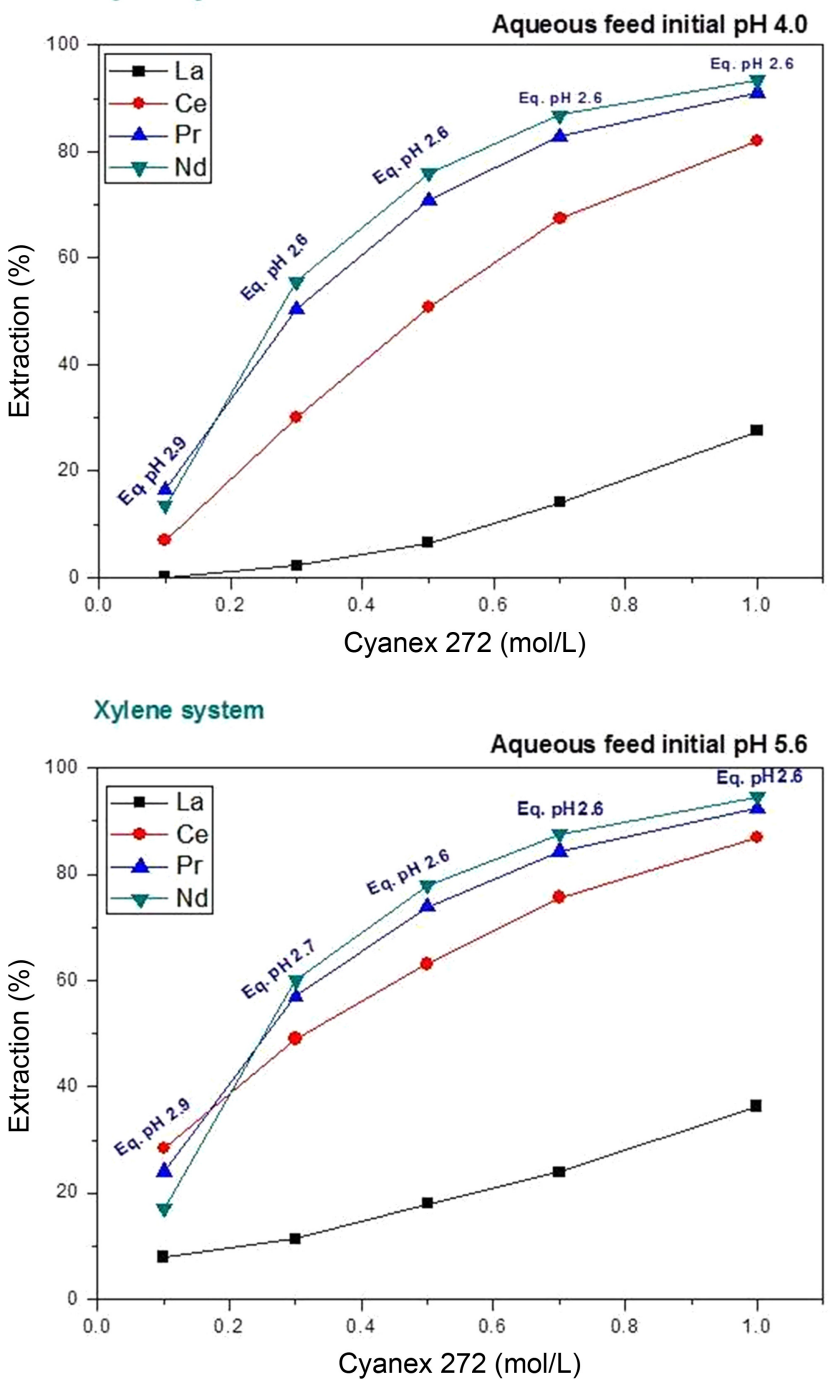

Fig. 4. Influence of the $\mathrm{pH}$ on the extraction and possible separation of LRE's using Cyanex ${ }^{\mathbb{B}} 272$ as an extractant diluted in xylene.

\subsection{Studies of separation factors (SFs)}

The potential for separation of the LRE's is presented in Tables 1 to 3. As noted, extraction of LRE's was generally poor below $\mathrm{pH}$ 2. Table 1 presents the benzene diluent system. Separation of $\mathrm{Nd}$ from $\mathrm{La}$ showed the highest calculated SF of 65.7 at an initial pH of 4 (Eq. pH 2.5) with $1.0 \mathrm{~mol} / \mathrm{L} \mathrm{Cyanex}{ }^{\circledR} 272$. This is expected because $\mathrm{Nd}$ is the most strongly extracted and La is the most weakly extracted. Separation factors for $\mathrm{Nd} / \mathrm{Pr}$ and $\mathrm{Nd} / \mathrm{Ce}$ were around 2.6-2.8 and 1.3-1.4 respectively, again following the order of elements preferred by the extractant.

In the toluene system, the separation factors were about the same as in the benzene system. The xylene system produced the highest $\mathrm{Nd} / \mathrm{La}$ separations, but in a $\mathrm{pH}$ range where overall extraction was not as good. It was also found that the highest SFs were those of the xylene system (up to SF with a $\mathrm{D}_{\mathrm{Nd}} / \mathrm{D}_{\mathrm{La}}$ ratio of 192 at lower $\mathrm{pH}$ conditions (not shown here)), followed by benzene (SF with a $\mathrm{D}_{\mathrm{Nd}} / \mathrm{D}_{\mathrm{La}}$ ratio of 65.6) and toluene (SF with a $\mathrm{D}_{\mathrm{Nd}} / \mathrm{D}_{\mathrm{La}}$ ratio of 30.3 ). The $\mathrm{SF}$ data indicate that the studied benzene and xylene systems are feasible in the $\mathrm{pH}$ range of 3 to 5.6; whereas the toluene system at $\mathrm{pH} 2$ is feasible, but under this condition the extraction efficiencies were very low.

\subsection{Possible extraction mechanism}

Based on the influence of $\mathrm{pH}$ and extractant concentration on LRE extraction the processing mechanism can be predicted. The reported literature indicates that the ionexchange mechanism was observed in many cases $[13,14]$. Similar extraction behavior was observed in the present study and the following extraction reaction is proposed:

$$
\mathrm{LRE}^{n+}+\mathrm{m}\left(\mathrm{H}_{2} \mathrm{~A}_{2}\right)=\operatorname{LRE}\left(\mathrm{HA}_{2}\right)_{\mathrm{n}}+m \mathrm{H}^{+}
$$

Here, LRE = Light rare earths such as Lanthanum, Cerium, Praseodymium and Neodymium, $\mathrm{H}_{2} \mathrm{~A}_{2}=$ Cyanex 272, $\mathrm{n}$ (or) $\mathrm{m}=$ Numerical numbers such as $1,2,3 \ldots$.

\subsection{Loading capacity of the extractant $\left(\right.$ Cyanex $^{\circledR}$} 272)

The loading capacity of the extractant is significant from industrial and commercial standpoints. In the present study, $0.7 \mathrm{~mol} / \mathrm{L}$ of Cyanex ${ }^{\circledR} 272$ was dissolved in different diluents, in this case benzene, toluene and xylene. They were tested to 
Table 1. Separation factor data for Cyanex ${ }^{\circledR} 272$-benzene system.

\begin{tabular}{|c|c|c|c|c|c|c|c|c|}
\hline \multicolumn{9}{|c|}{ 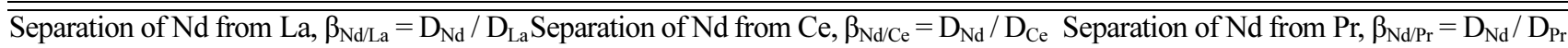 } \\
\hline $0.5 \mathrm{~mol} / \mathrm{L} \mathrm{Ex}$ & $0.7 \mathrm{~mol} / \mathrm{L} \mathrm{Ex}$ & $1.0 \mathrm{~mol} / \mathrm{L} \mathrm{Ex}$ & $0.5 \mathrm{~mol} / \mathrm{L} \mathrm{Ex}$ & $0.7 \mathrm{~mol} / \mathrm{L} \mathrm{Ex}$ & $1.0 \mathrm{~mol} / \mathrm{L} \mathrm{Ex}$ & $0.5 \mathrm{~mol} / \mathrm{L} \mathrm{Ex}$ & $0.7 \mathrm{~mol} / \mathrm{L} \mathrm{Ex}$ & $1.0 \mathrm{~mol} / \mathrm{L} \mathrm{Ex}$ \\
\hline 30.8 & 29.7 & 36.0 & 2.6 & 2.6 & 2.7 & 1.2 & 1.3 & 1.3 \\
\hline 20.7 & 28.3 & 65.7 & 2.6 & 2.6 & 2.7 & 1.2 & 1.4 & 1.3 \\
\hline 28.9 & 28.7 & 34.2 & 2.4 & 2.4 & 2.6 & 1.2 & 1.3 & 1.3 \\
\hline
\end{tabular}

Ex $=$ Cyanex $^{\circledR} 272$

Table 2. Separation factor data for Cyanex ${ }^{\circledR} 272$-toluene system.

\begin{tabular}{ccccccccc}
\hline \hline \multicolumn{5}{c}{ Separation of $\mathrm{Nd}$ from $\mathrm{La}, \beta_{\mathrm{Nd} / \mathrm{La}}=\mathrm{D}_{\mathrm{Nd}} / \mathrm{D}_{\mathrm{La}}$ Separation of $\mathrm{Nd}$ from Ce, $\beta_{\mathrm{Nd} / \mathrm{Ce}}=\mathrm{D}_{\mathrm{Nd}} / \mathrm{D}_{\mathrm{Ce}}$ Separation of Nd from Pr, $\beta_{\mathrm{Nd} / \mathrm{Pr}}=\mathrm{D}_{\mathrm{Nd}} / \mathrm{D}_{\mathrm{Pr}}$} \\
\hline $0.5 \mathrm{~mol} / \mathrm{L} \mathrm{Ex}$ & $0.7 \mathrm{~mol} / \mathrm{L} \mathrm{Ex}$ & $1.0 \mathrm{~mol} / \mathrm{L} \mathrm{Ex}$ & $0.5 \mathrm{~mol} / \mathrm{L} \mathrm{Ex}$ & $0.7 \mathrm{~mol} / \mathrm{L} \mathrm{Ex}$ & $1.0 \mathrm{~mol} / \mathrm{L} \mathrm{Ex}$ & $0.5 \mathrm{~mol} / \mathrm{L} \mathrm{Ex}$ & $0.7 \mathrm{~mol} / \mathrm{L} \mathrm{Ex}$ & $1.0 \mathrm{~mol} / \mathrm{L} \mathrm{Ex}$ \\
\hline 19.4 & 22.8 & 27.6 & 2.0 & 2.1 & 2.3 & 1.1 & 1.1 & 1.2 \\
17.1 & 23.5 & 28.5 & 2.0 & 2.3 & 2.4 & 1.1 & 1.2 & 1.3 \\
28.1 & 29.7 & 30.2 & 2.0 & 2.2 & 2.5 & 1.2 & 1.2 & 1.3 \\
\hline
\end{tabular}

Ex $=$ Cyanex $^{\circledR} 272$

Table 3. Separation factor data for Cyanex ${ }^{\circledR} 272$-xylene system.

\begin{tabular}{|c|c|c|c|c|c|c|c|c|}
\hline \multicolumn{9}{|c|}{ 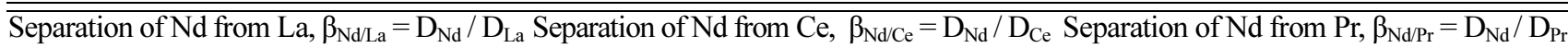 } \\
\hline $0.5 \mathrm{~mol} / \mathrm{L} \mathrm{Ex}$ & $0.7 \mathrm{~mol} / \mathrm{L} \mathrm{Ex}$ & $1.0 \mathrm{~mol} / \mathrm{L} \mathrm{Ex}$ & $0.5 \mathrm{~mol} / \mathrm{L} \mathrm{Ex}$ & $0.7 \mathrm{~mol} / \mathrm{L} \mathrm{Ex}$ & $1.0 \mathrm{~mol} / \mathrm{L} \mathrm{Ex}$ & $0.5 \mathrm{~mol} / \mathrm{L} \mathrm{Ex}$ & $0.7 \mathrm{~mol} / \mathrm{L} \mathrm{Ex}$ & $1.0 \mathrm{~mol} / \mathrm{L} \mathrm{Ex}$ \\
\hline 37.6 & 37.8 & 39.0 & 3.1 & 3.2 & 3.2 & 1.5 & 1.5 & 1.5 \\
\hline 45.5 & 40.3 & 37.1 & 3.0 & 3.1 & 3.0 & 1.3 & 1.3 & 1.3 \\
\hline 16.2 & 22.5 & 30.6 & 2.0 & 2.2 & 2.6 & 1.2 & 1.3 & 1.4 \\
\hline
\end{tabular}

Ex $=$ Cyanex $^{\circledR} 272$
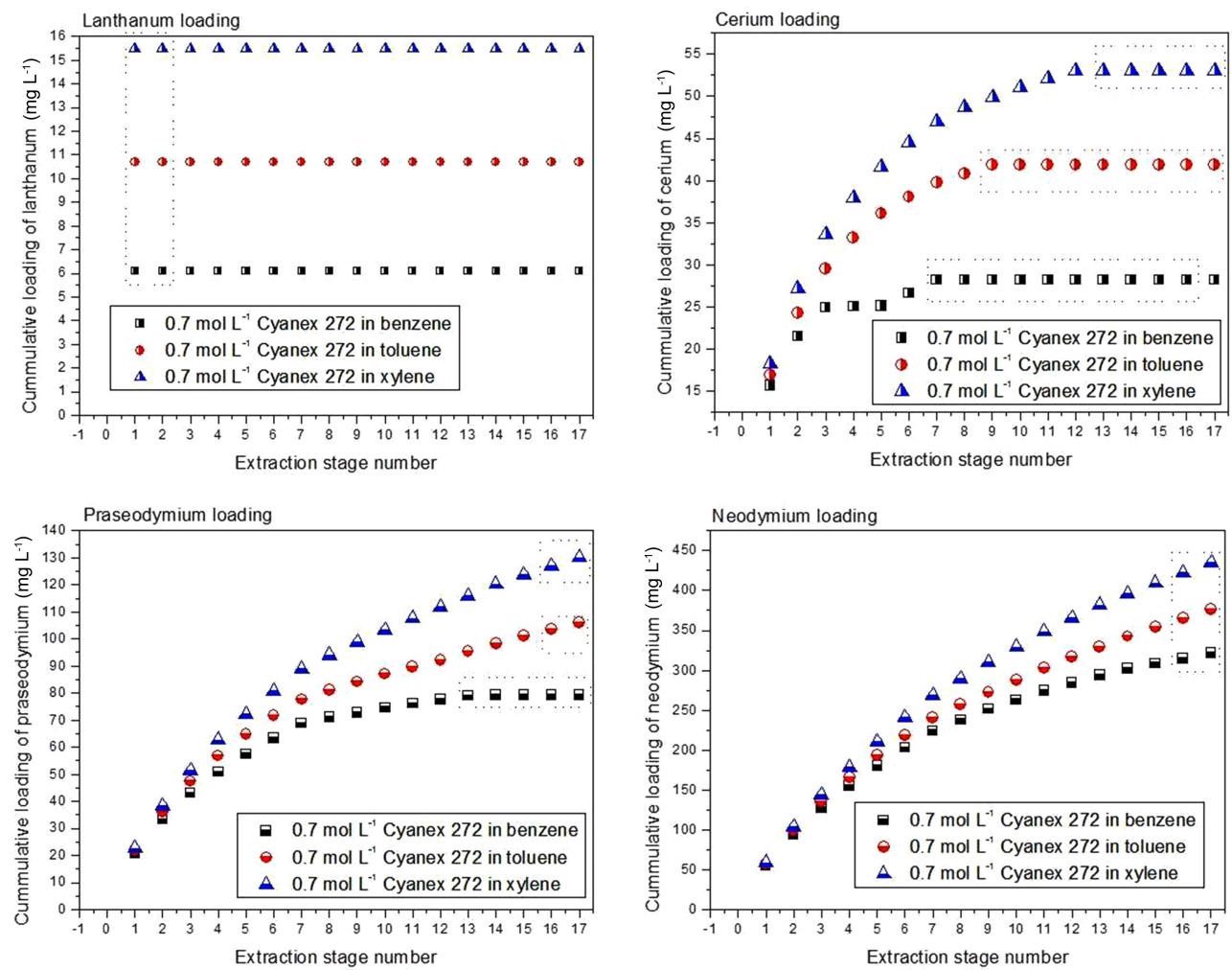

Fig. 5. Loading capacity of extractant $\left(\right.$ Cyanex $\left.^{\circledR} 272\right)$ of light rare earth elements extraction from chloride solutions. 


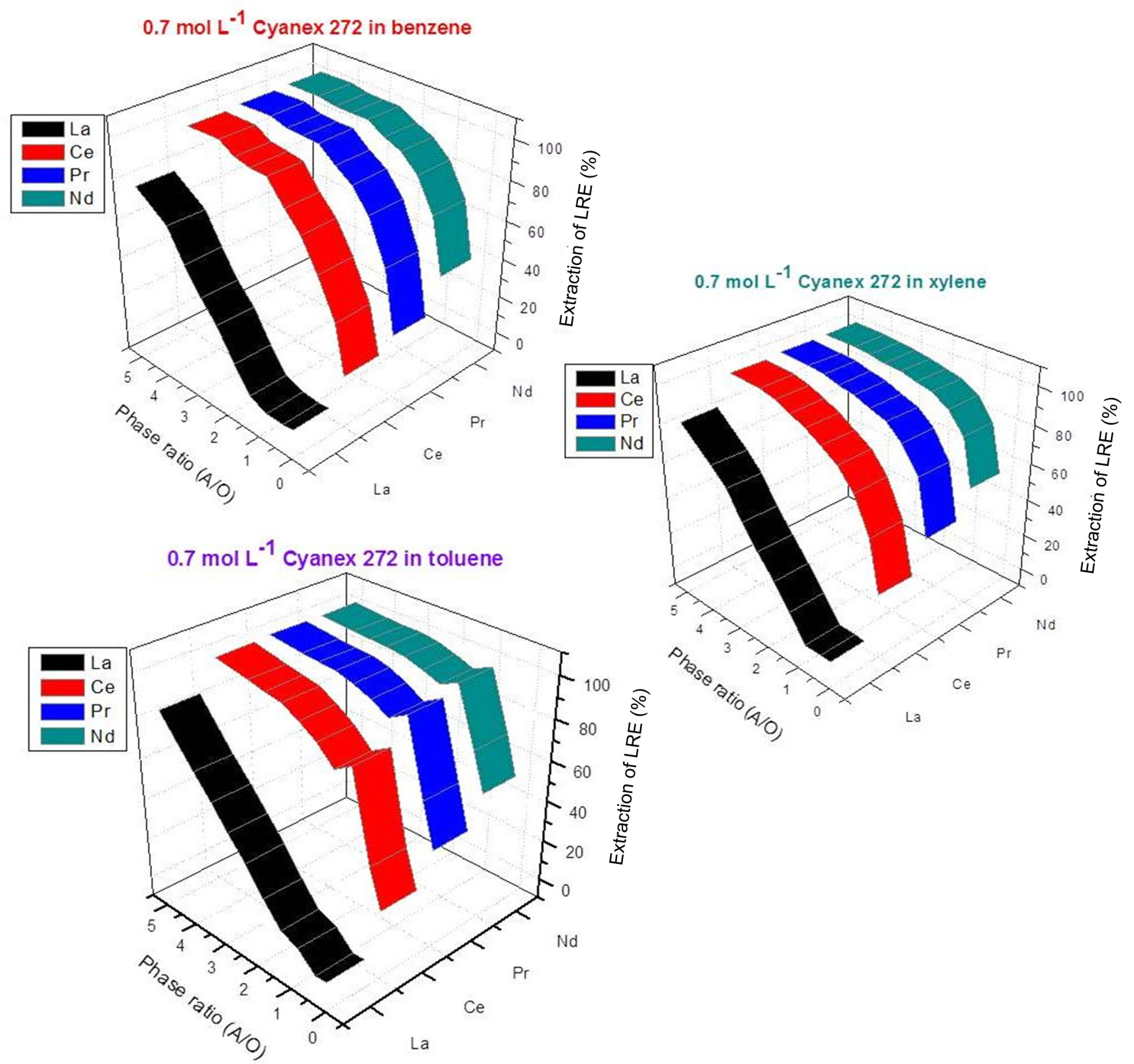

Fig. 6. Effect of the phase ratio (aqueous / organic) on light rare earth extraction rate from chloride solutions using Cyanex ${ }^{\circledR} 272$ as an extractant system with the diluents of benzene, toluene, and xylene.

assess the maximum loading capacity by adding them simultaneously in an aqueous feed to an identical organic phase, up to the metal saturation point. All three systems, up to fifteen extraction stages (one-by-one), were not saturated by the maximum loading of the LRE's. The total extraction stages tested individually for up to seventeen stages (Fig. 5). Overall, the order of loading capacity extraction efficiency was as follows: toluene $>$ xylene $>$ benzene.

\subsection{Effect of the phase ratio on the extraction process for light rare earth elements}

Various phase ratios were changed and tested to assess the LRE extraction and potential for separation using Cyanex ${ }^{\circledR}$
272 as an extractant system, and the three different diluents of benzene, toluene and xylene were utilized to determine the best organic phase media. The aqueous versus organic phases were varied from 0.2 to 5.0 at a temperature of $25^{\circ} \mathrm{C}$, and the initial $\mathrm{pH}$ condition was $5.6 \pm 0.1$ (the equilibrium $\mathrm{pH}$ was $2.5 \pm 0.1$ ), with $0.7 \mathrm{~mol} / \mathrm{L}$ of Cyanex ${ }^{\circledR} 272$ dissolved individually in the three different diluents of benzene, toluene and xylene to determine the phase ratio effect. For all three diluents, the percentage of extraction of the LRE's increased with an increase in the phase ratio (Figure 6). Except for lanthanum, the remaining three LRE's reached 97\%, whereas for lanthanum the highest extraction observed was between $78 \%$ and $83 \%$. It started to saturate at the maximum loading of the 

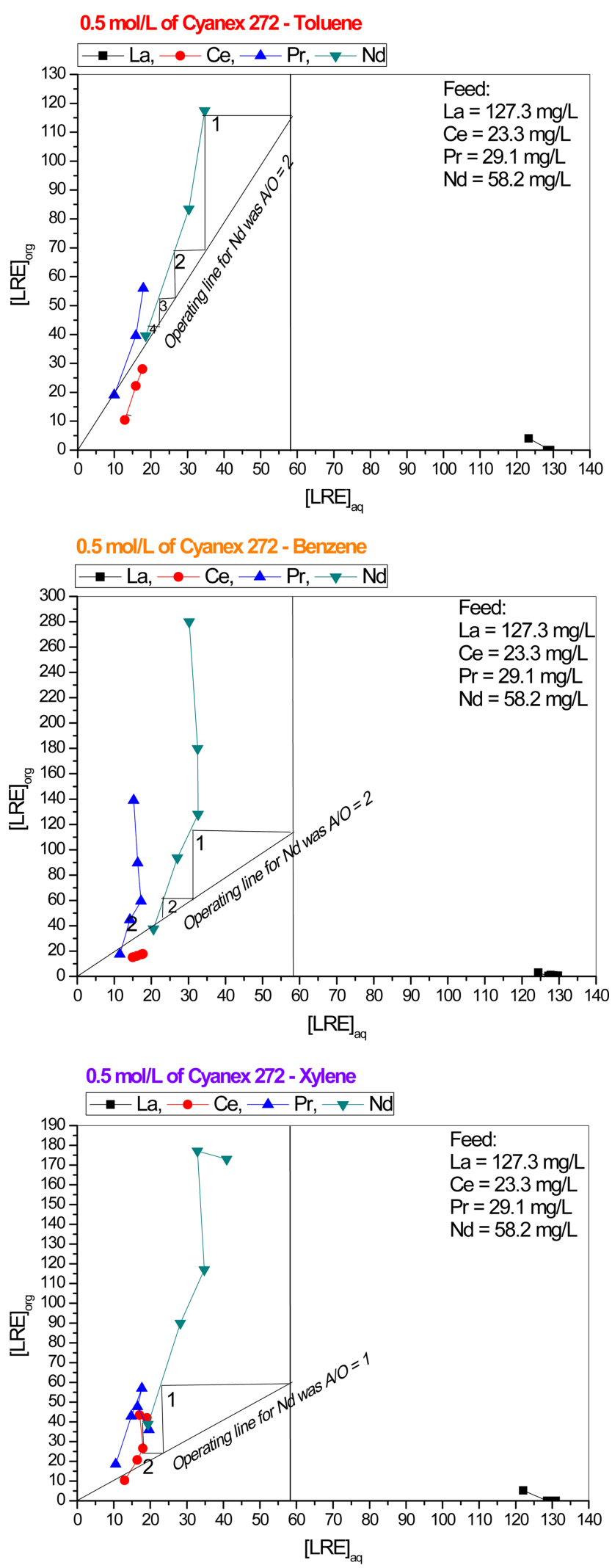

Fig. 7. Extraction isotherm for LRE's using Cyanex ${ }^{\circledR} 272$ as an extractant system with diluents of benzene, toluene, and xylene. metal from a phase ratio of A/O 3 onwards. Even for metals such as $\mathrm{Pr}$ and $\mathrm{Nd}, \mathrm{A} / \mathrm{O} 2$ is enough of a load to reach the maximum capability of the metal.

\subsection{Extraction isotherms for LRE's using Cyanex ${ }^{\circledR}$ 272 as an extractant}

The extraction isotherm will give information about the required phase ratio and the number of extraction stages to reach the maximum metal extraction rate from an aqueous to an organic phase. In the present study, the $\mathrm{A} / \mathrm{O}$ was varied from 1 to 10. The obtained data are presented in Fig. 7. The data indicate that lanthanum was extracted at a negligible rate (and sometimes nil); the present experiment determined the number of extraction stages for $\mathrm{Nd}, \mathrm{Pr}$, and $\mathrm{Ce}$. With the Cyanex $^{\circledR}$ 272-benzene system, two extraction stages are required for $\mathrm{Nd}$ and $\mathrm{Pr}$ when the $\mathrm{A} / \mathrm{O}$ ratio is 2 for $\mathrm{Nd}$ and 2.9 for $\mathrm{Pr}$, whereas the toluene system requires four extraction stages for $\mathrm{Nd}$, three for $\mathrm{Pr}$ and two for Ce with corresponding phase ratios of $2,1.8$, and 1 . The other system, xylene, requires three extraction stages for $\mathrm{Nd}$ with a phase ratio of three and two for Pr or Ce with a phase ratio of 2 (Fig. 7).

\section{CONCLUSIONS}

Three different types of aromatic diluents were tested in the present study. These were benzene, toluene and xylene, and the difference between each diluent was the addition of one methyl group. A kinetic study concluded that the three diluents could rapidly reach equilibrium within one minute. The influence of the initial $\mathrm{pH}$ study concluded that 3 to 5.64 is the better range when compared to a lower range (1 to 2). The extractant concentration was varied from 0.1 to $1.0 \mathrm{~mol} /$ L of Cyanex ${ }^{\circledR} 272$, and the percentage of extraction increased with an increase in the extractant concentration. The maximum loading capacity test found the following order of preference $(\mathrm{Nd}$ loading): toluene $>$ xylene $>$ benzene. Overall separation factors were calculated, finding a diluent order as follows: xylene $>$ benzene $>$ toluene. Extraction isotherm studies concluded that two extraction stages with $\mathrm{A} / \mathrm{O}$ equal to 2 are required in the Cyanex ${ }^{\circledR}$ 272-benzene system for $\mathrm{Nd}$, whereas a phase ratio of 2.9 for Pr was observed in the same system. In the toluene system, four extraction stages are 
required for $\mathrm{Nd}$ with an $\mathrm{A} / \mathrm{O}$ ratio of 2 and three stages are required for $\mathrm{Pr}$ with, an $\mathrm{A} / \mathrm{O}$ ratio of 1.8 . For the Cyanex ${ }^{\circledR}$ 272-xylene system, three extraction stages for an $\mathrm{A} / \mathrm{O}$ ratio of 3 for $\mathrm{Nd}$ and two stages for an $\mathrm{A} / \mathrm{O}$ ratio of 2 for Pr or $\mathrm{Ce}$ are needed. This study indicates that the benzene system is more suitable for good extraction and possible separation. Future studies will concentrate on the development of counter-current and stripping processes. Future studies will also focus on metal extraction enrichment and possible separation of adjacent rare earths.

\section{ACKNOWLEDGEMENTS}

The authors Dr. Jin-Young Lee and Dr. Rajesh Kumar Jyothi express their sincere gratitude to the Convergence Research Project (CRC-15-06-KIGAM), funded by the National Research Council of Science and Technology (NST) as well as the authorities of the Korea Institute of Geoscience and Mineral Resources (KIGAM) funded by the Ministry of Science, ICT, and Future Planning of Korea. The author Professor Joon Soo Kim expresses his deep thanks to the authorities of Chonnam National University, Korea, and the author Ms. Hey-Rim Kim expresses her sincere thanks to the Korea Resources Corporation (KORES) and the authorities there.

\section{REFERENCES}

1. Critical Materials Strategy, US Department of Energy, USA (2010).

2. Valerie Bailey Grasso, Rare Earth Elements in National Defense: Background, Oversight Issues, and Options for Congress, Congressional Research Service, USA (2013).

3. D. Alami, Environ. Eng. Res. 18, 211 (2013).

4. D. Schüler, "Rare Earths-Facts and Figures", (https:// www.oeko.de/fileadmin/pdfs/oekodoc/1111/2011-002en.pdf) (2011).

5. R. D. Gomes, L. A. Seruff, M. L. W. Scal, and Y. M. Vera, Metall. Mater. Trans. B 49B, 460 (2018).

6. S. Radhikaa, B. N. Kumara, M. L. Kantama, and B. R. Reddya, Sep. Purif. Technol. 75, 295 (2010).

7. J. S. Kim, B. N. Kumar, J. Y. Lee, M. L. Kantam, and B. R. Reddy, Sep. Sci. Technol. 47, 1644 (2012).

8. R. Banda, H. S. Jeon, and M. S. Lee, Hydrometallurgy 121124, 74 (2012).

9. R. Banda, H. S. Jeon, M. S. Lee, Sep. Purif. Technol. 98, 481 (2012).

10. V. P. Shvedov, A. A. Kopyrin, and V. S. Titov, J. Radioanal. Chem. 33, 223 (1976).

11. Y. Cui, J. Yang, G. Yang, G. Xia, Y. Nie, and G. Sun, Hydrometallurgy 121-124, 16 (2012).

12. Y. Liu, H. S. Jeon, and M. S. Lee, Korean J. Met. Mater. 54, $592(2016)$

13. J. S. Kim, B. N. Kumar, J. Y. Lee, M. L. Kantam, and B. R. Reddy, Sep. Sci. Technol. 47, 1644 (2012).

14. J. E. Quinn, K. H. Soldenhoff, G. W. Stevens, and N. A. Lengkeek, Hydrometallurgy 157, 298 (2015). 